\title{
Contaminated dredged soil stabilization using cement and bottom ash for use as highway subgrade fill
}

\author{
Anjali Gupta ${ }^{1 *}$, V. K. Arora ${ }^{1}$ and Srijit Biswas ${ }^{2}$
}

*Correspondence:
anjaligupta.eng@gmail.com
${ }^{1}$ Department of Civil
Engineering, National
Institute of Technology,
Kurukshetra, India
Full list of author information
is available at the end of the
article

*Correspondence: anjaligupta.eng@gmail.com Engineering, National Institute of Technology, article

\begin{abstract}
Large amount of sediments are dredged from connecting drains of River Yamuna as a part of its regular maintenance in Delhi. These dredged soils generally considered as waste due to its poor engineering properties. In this study attempt has been made to improve strength, durability and immobilize contaminants of the contaminated dredged soil collected from Najafgarh drain by mixing it with different proportion of cement-bottom ash mix so that it can suitably fulfill the requirements of highway subgrade materials. Compaction test, California bearing ratio test, wetting and drying test, toxicity characteristic leaching procedure leachate test and scanning electron microscope test were performed on the contaminated dredged soil specimens and the results indicated that cement-bottom ash mix was effective in improving the engineering properties of the contaminated dredged soils. Also, the test results of the contaminated dredged soil stabilized with cement-bottom ash mix were better in comparison to cement alone. From the study it reveals that the optimum proportion of additive to be used to improve properties of the contaminated dredged soils was 10\% cement $+10 \%$ bottom ash mix for use it as a highway subgrade fill materials.
\end{abstract}

Keywords: Bottom ash, Cement, Contaminated dredged soils, Stabilization, Subgrade fill etc.

\section{Introduction}

The River Yamuna is a most important river of Delhi, capital of India and stretched within the zone of $22 \mathrm{~km}$ from Wazirabad to Okhala. Within this stretch 22 major drains of the capital, Delhi is connected and continuously discharging highly contaminated sediments, sewage and sludge effluents directly into it resulting in the rise of its bed level due to siltation day by day [5]. Thus, before monsoon every year dredging of the soils from each drain becomes essential. As recorded during 2010-2013 the total quantity of dredged soils removed from all the drains is approximately 8, 30,000 $\mathrm{m}^{3}$ and in 2016 the quantity of dredged soil removed is about $3,38,132 \mathrm{~m}^{3}$ [17]. Due to scarcity of open land, the Government of Delhi is facing great problems to dispose these high quantities of dredged soils every year. The earlier practice of dumping of dredged soils into landfill areas or into open places caused a lot of environmental problems and suffering to local public which forced management authority for alternative solutions of its disposal. Currently, stabilization and solidification $(\mathrm{S} / \mathrm{S})$ processes have been recognized

(c) The Author(s) 2017. This article is distributed under the terms of the Creative Commons Attribution 4.0 International License (http://creativecommons.org/licenses/by/4.0/), which permits unrestricted use, distribution, and reproduction in any medium, provided you give appropriate credit to the original author(s) and the source, provide a link to the Creative Commons license, and indicate if changes were made. 
to treat such type of contaminated dredged soils containing heavy metals and to use it as valuable resources. Wilk et al. [28] reported the stabilization and reuse of contaminated dredged material from Former Wood Treating Facility, Port Newark, New Jersey and New York harbour dredged sediments using cement. He found that dredged material from Port Newark when treated with $8 \%$ cement achieved unconfined compressive strength greater than 1.7 $\mathrm{MPa}$ which was suitable for its use as base material for pavement whereas the dredged soil from New York harbour site got stabilized to be used as structural fill. Lahtinen et al. [21] reported the utilization of marine dredged sediments by stabilizing it with cement and industrial waste products such as flyash, blast furnance slag, oil shale ash, flu gas desulphurization gypsum, in ABSOILS and STABLE projects, Finland. In ABSOILS project, dredged sediments were stabilized with cement and fly ash and utilized for various infrastructure construction purposes in the city of Helsinki. In the STABLE project on Aurajoki River, contaminated dredged river sediments were mass stabilized with mix of cement, slag and fly ash and utilized in harbour construction as a filling material. Maher et al. [22] through a demonstration project studied the suitability of contaminated dredged soil as stable embankment fill material after stabilization. The results of study revealed that contaminated dredged soil which is silty in nature on addition of $8 \%$ cement showed significant improvement in it's compaction characteristics and also performed satisfactorily to be used as a stable embankment fill material. From the above literature it has been found that for stabilization of contaminated dredged soils, cement has been the most popular and effective primary stabilizers among all the varieties of soil stabilizers and other industrial wastes if added act as auxiliary stabilizers. From further series of studies [4, 9, 18, 24], it delineate that bottom ash can also be used as partial replacement of cement as well as replacement of natural sand, aggregates due to it's Pozzolanic characteristics and it's similar particle size distribution etc. But excessive use of cement amount can cause negative impact on cost $[7,23]$ and in other way bottom ash is also a big environmental problem for its safe disposal today.

The present study deals with the problems of safe disposal of two major wastes: contaminated dredged soils and bottom ash being main contemporary environmental problems. In this study, attempt has been made to stabilize contaminated dredged soils with bottom ash as a partial replacement of cement and to evaluate improvement in its properties relevant to be used as highway subgrade fill aiming at eco-friendly use of both wastes materials in highway construction.

\section{Materials and methods used}

In this section we discussed materials used for study along with the methodology.

\section{Materials}

\section{Dredged soil}

The soil used in this study was collected from Najafgarh drain one of the major connecting drain of Yamuna River where dredging work was in progress. Figure 1a, b shows the dredging at site using backhoe dredger and materials dumping along both the banks of the Najafgarh drain during the period of case study. 


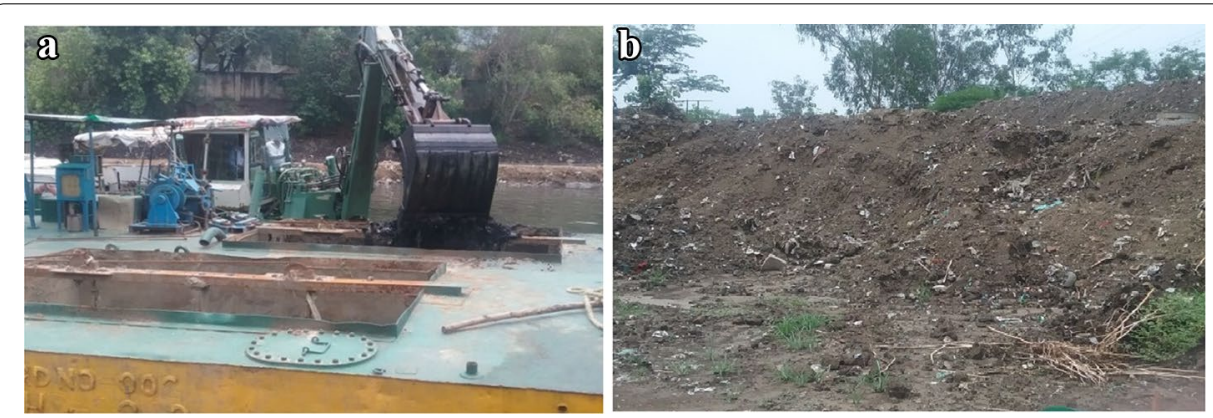

Fig. 1 a Dredging of Nazafgarh Drain. b Dumping of dredged soils along banks

To characterize the dredged soil its geotechnical, chemical, mineralogical and morphological properties were tested. Also, leachate properties showing heavy metal concentration of dredged soils were studied.

The geotechnical properties of dredged soil are presented in Table 1. From the grain size test results the soil is classified as "ML" as per IS classification indicating that soil is 'Silt of low compressibility' [13]. The results of leachate test for heavy metal concentration are presented in Table 2.

The Scanning Electron Microscope test (SEM) results of the contaminated dredged soil are presented at two different magnifications i.e. at $\times 500$ and at $\times 5000$ as shown in Fig. 2a, b. From both the figures it has been observed that soil grains have rough surface texture with semiangular shape and large voids. Presence of heavy metal is also identified in magnifications at $\times 5000$ as shown in Fig. $2 b$.

\section{Table 1 Geotechnical properties of dredged soil}

\begin{tabular}{ll}
\hline Property & Value \\
\hline Water content (in-situ) (\%) & 28 \\
Grain size distribution & 4 \\
Gravel (\%) & 34 \\
Sand (\%) & 60 \\
Silt (\%) & 2 \\
Clay (\%) & 10.76 \\
Coefficient of uniformity (Cu) & 4.45 \\
Coefficient of curvature (Cc) & 2.52 \\
Specific gravity & \\
Atterberg's limit & 20.99 \\
Liquid limit (\%) & Non plastic \\
Plastic limit (\%) & Nil \\
Differential free swell index & \\
Compaction characteristics & 1.64 \\
Max dry density (MDD) (g/cm $\left.{ }^{3}\right)$ & 13.5 \\
Optimum moisture content (OMC) (\%) & \\
CBR (\%) & 1.45 \\
Unsoaked & 1.03 \\
Soaked & 197.11 \\
Unconfined compressive strength (kPa) & 2.15 \\
Organic matter (\%) & \\
\hline
\end{tabular}


Table 2 Heavy metal concentration in dredged soil

\begin{tabular}{lc}
\hline Metals & Concentration $\mathbf{( m g / l ~ o r ~ p p m ) ~}$ \\
\hline Nickel & 383.0 \\
Chromium & 109.0 \\
Zinc & 2660.0 \\
Lead & 74.5 \\
Cadmium & 27.1 \\
\hline
\end{tabular}

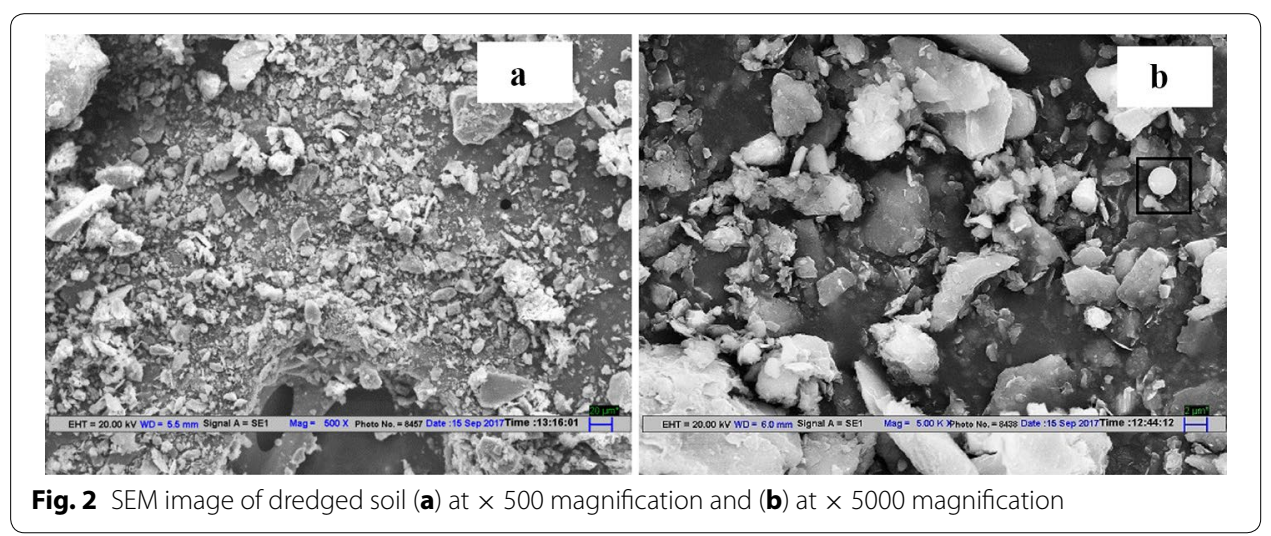

\section{Stabilizing agent}

For stabilizing the dredged soils, we used 'Ordinary Portland Cement (OPC)' and 'Bottom Ash' of thermal power plant as additives. Bottom Ash is produced from unburned or incomplete combustion of coal materials which is not entrained in flue gases or captured as 'Fly Ash'. Generally in any coal burning plant, bottom ash forms $15-25 \%$ of the total ash and rest as fly ash. The bottom ash under study was collected from National Thermal Power Plant at Badarpur, Delhi as shown in Fig. 3. The chemical composition of bottom ash is given in Table 3 .

The grain size analysis of bottom ash is shown in Fig. 4 and the coefficient of curvature and coefficient of uniformity were found as 2.13 and 0.60 respectively. Thus, bottom ash can be classified as poorly graded.

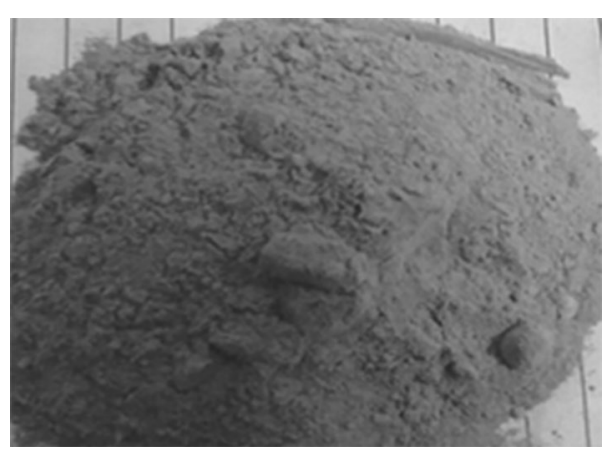

Fig. 3 Bottom ash used in present study 
Table 3 Chemical composition of bottom ash

\begin{tabular}{lllllllll}
\hline $\mathrm{SiO}_{\mathbf{2}}(\%)$ & $\mathrm{Fe}_{\mathbf{2}} \mathbf{O}_{\mathbf{3}}(\%)$ & $\mathbf{A l}_{\mathbf{2}} \mathbf{O}_{\mathbf{3}}(\%)$ & $\mathbf{C a O}(\%)$ & $\mathbf{M g O}(\%)$ & $\mathrm{Na}_{\mathbf{2}} \mathbf{O}(\%)$ & $\mathbf{K}_{\mathbf{2}} \mathbf{O}(\%)$ & $\mathbf{S O}_{\mathbf{3}}(\%)$ & Loss of ignition \\
\hline 44.82 & 10.50 & 26.27 & 5.83 & 1.15 & 0.40 & 0.28 & 0.39 & 9.44
\end{tabular}

The Chemical composition of ordinary Portland cement (Grade 43) used in this case study is given in Table 4 .

\section{Testing procedure}

Experimental programme comprises of preparation of specimens of dredged soil on addition of cement and also the mix of cement and bottom ash (1:1 ratio) aiming at the partial replacement of cement quantity. Kogbara [20] reviewed that the OPC dosage for contaminated soil may range from 4 to $20 \%$ by weight of dry mass. On basis of that the mixing proportion of cement and cement-bottom ash mix with dredged soil is taken as $4-20 \%$ by weight of the dry soil. The results of all the samples mixed with cement only are considered as reference so as to compare the results of samples mixed with cementbottom ash mix and to ascertain the quantity of cement replaced by bottom ash. The summary of the test specimens prepared for the study are presented in Table 5 where ' $C$ ' stands for cement; and 'CBA' for cement-bottom ash mix.

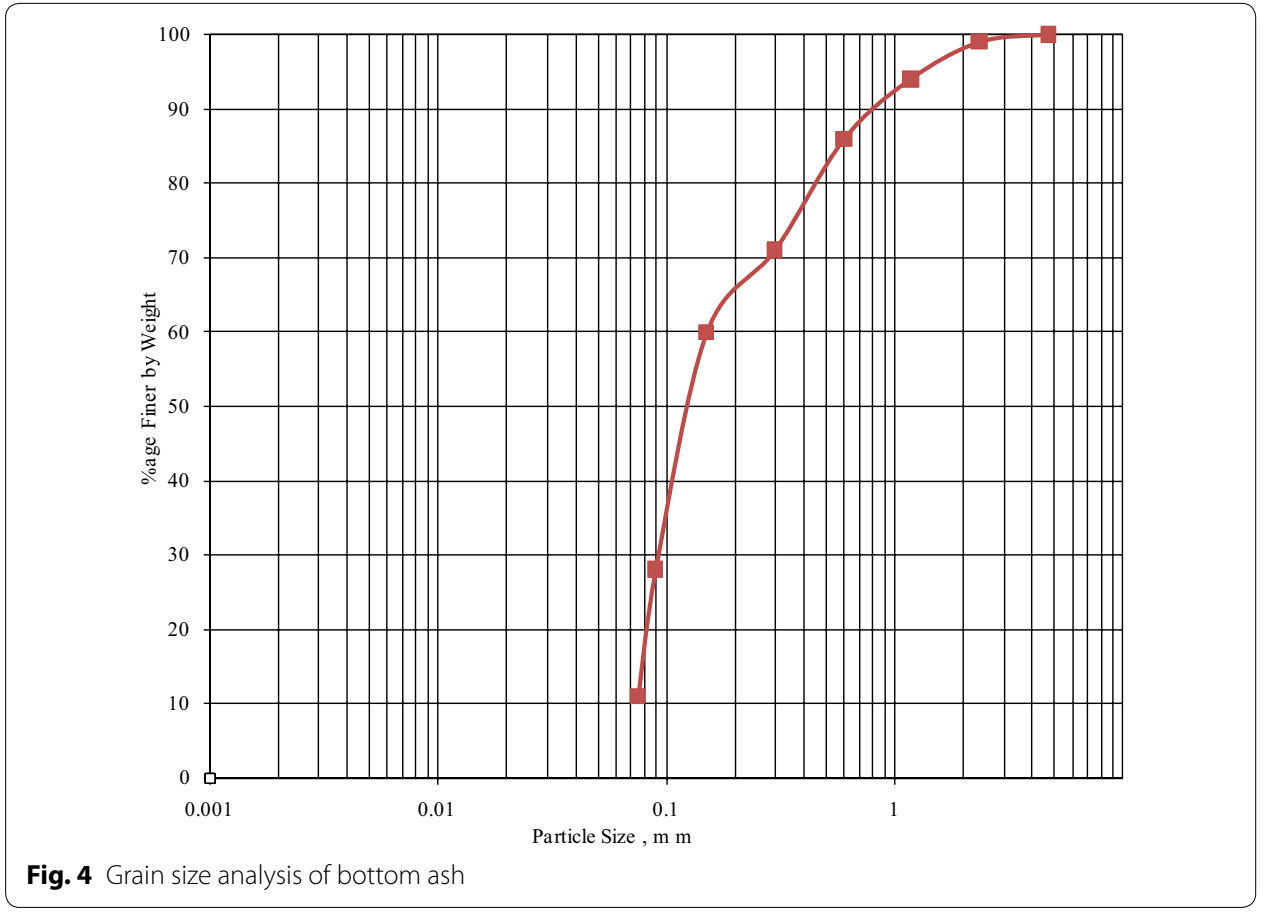

Table 4 Chemical composition of ordinary Portland cement

\begin{tabular}{lcccr}
\hline $\mathrm{SiO}_{\mathbf{2}}(\%)$ & $\mathrm{Fe}_{\mathbf{2}} \mathbf{O}_{\mathbf{3}}(\%)$ & $\mathbf{A l}_{\mathbf{2}} \mathbf{O}_{\mathbf{3}}(\%)$ & $\mathbf{C a O}(\%)$ & $\mathbf{M g O}(\%)$ \\
\hline $20 \pm 1$ & $3 \pm 0.5$ & $5 \pm 0.5$ & $61 \pm 1$ & $2.5 \pm 1$ \\
\hline
\end{tabular}


A series of laboratory tests such as standard Proctor compaction tests, California bearing ratio (CBR) tests, wetting and drying tests and Leachate tests were performed and the optimum binder content was then selected on the basis of stabilized soil acceptance criteria for highway subgrade fill. The SEM tests were also performed to ascertain the shape, surface texture and the microstructure bonding of soil grains in soil samples.

The standard Proctor compaction test was conducted as per IS 2720-7 [14]/ASTM D 698 [2] on all the specimens. In each case mould of diameter $100 \mathrm{~mm}$ and height $127.3 \mathrm{~mm}(1000 \mathrm{ml})$ was used and specimens were compacted in three equal layers by rammer of weight $2.6 \mathrm{~kg}$ and free fall of $310 \mathrm{~mm}$. Special care was taken for the stabilized specimens by compacting it within 20 min of completion of mixing with cement and bottom ash.

The specimens for performing CBR tests were prepared in a cylindrical mould of $150 \mathrm{~mm}$ diameter and $175 \mathrm{~mm}$ height by compacting specimen at their respective max dry density (MDD) and optimum moisture content (OMC) and tested in accordance with IS 2720-16 [15]/ASTM D1883-16 [3]. The tests on raw dredged soil specimens were performed in unsoaked conditions and 4 days soaking conditions whereas for dredged soil which was stabilized with different amount of cement and cement-bottom ash mix initial curing for 3 days by maintaining 100\% humidity followed by soaking in water for 4 days as mentioned in IRC 50 [11] was done. All specimens were tested using a shear rate of $1.25 \mathrm{~mm} / \mathrm{min}$ and load readings were recorded at penetrations of $0.5,1.0,1.5,2.0$, 2.5, 3.0, 4.0, 5.0, 7.5, 10 and $12.5 \mathrm{~mm}$. Graphs were plotted between the penetration and load and CBR values were calculated for penetration of 2.5 and $5 \mathrm{~mm}$.

According to IRC 37 [10], the minimum CBR value of soil to be used for subgrade should be $8 \%$ whereas Federal Ministry of Works and Housing [8] recommends that CBR value for subgrade should not be less than $10 \%$ under soaked condition. Schaefer et al. [26] reported that subgrade CBR value should be at least $10 \%$. Specimens which fulfilled both (Indian and International) CBR criteria i.e. maximum $10 \%$ were tested for durability.

Table 5 Mix proportion of different specimens (\%age by weight)

\begin{tabular}{lcc}
\hline Specimen & Cement (\%) & Bottom ash (\%) \\
\hline $4 C$ & 4 & 0 \\
$6 C$ & 6 & 0 \\
$8 C$ & 8 & 0 \\
$10 C$ & 10 & 0 \\
$12 C$ & 12 & 0 \\
$16 C$ & 16 & 0 \\
$20 C$ & 20 & 0 \\
$4 C B A$ & 2 & 2 \\
$6 C B A$ & 3 & 3 \\
$8 C B A$ & 4 & 4 \\
$10 C B A$ & 5 & 5 \\
$12 C B A$ & 6 & 6 \\
$16 C B A$ & 8 & 8 \\
$20 C B A$ & 10 & 10 \\
\hline
\end{tabular}


As study area belongs to non frost region, hence the durability test was conducted by wetting and drying method in accordance with IS 4332-4 [16]/ASTM D559/D559 M-15 [1]. The specimens of size $38 \mathrm{~mm}$ in diameter and $76 \mathrm{~mm}$ in height were prepared by compacting it statically in UCS mould to achieve MDD at OMC. The specimens were than ejected from mould using extractor and wrapped in polythene bag for $24 \mathrm{~h}$ to avoid any moisture loss. After that the specimens were cured for 7 days and thereafter were immersed in water for $5 \mathrm{~h}$ followed by drying in oven at $70{ }^{\circ} \mathrm{C}$ for $42 \mathrm{~h}$ which form one wet dry cycle. This test procedure continued up to 12 cycles. After end of each cycle the specimens were brushed along the height as well as diameter with a steel brush at approximately $1.4 \mathrm{kgf}$ force and soil cement losses were recorded in percentage. Portland Cement Association [25] has recommended that after completion of 12 wet dry cycles the soil-cement loss of granular soils of low plasticity and cohesive clays should not exceed limit of 14 and $7 \%$ respectively and for silty soil it should not exceed the limit of $10 \%$. But from some other studies the above recommended limits were found to be stringent. As mentioned in IRC SP 89 [12] soils are not permitted to loss 20, 30 and 30\% for its use for construction of base, subbase and shoulder respectively and for subgrade nothing has been specified. So, for the contaminated dredged soil which is silty in nature and for use in subgrade, the loss of soil-cement limit after completion of 12 wet dry cycles is considered as maximum $10 \%$ in this study.

Finally leachate test was performed by following Toxicity Characteristic Leaching Procedure (TCLP) defined by USEPA, Method 1311 [27] on the specimens which fulfilled allowed cement loss criteria. The specimens used in the testing were prepared in same manner as for wet and dry testing and cured for 7 and 28 days. For conducting leachate test prepared specimens were crushed to particle size less than $9.5 \mathrm{~mm}$ and transferred to extraction vessel. The extract used was type $2(\mathrm{pH} 2.88)$. To prepare the extraction fluid $5.7 \mathrm{ml}$ glacial acetic acid was diluted with distilled water to make 11 solution. The extraction fluid was added to $100 \mathrm{~g}$ of crushed soil sample maintaining 20:1 (L/S) ratio, and then rotated at $30 \pm 2 \mathrm{rpm}$ for $18 \pm 2 \mathrm{~h}$. Each solution was then filtered through a glass fiber filter, and preserved in order to avoid evaporation and volume changes. The samples were stored at $4{ }^{\circ} \mathrm{C}$ before analysis and analyzed for Cadmium (Cd), Zinc ( $\left.\mathrm{Zn}\right)$, Chromium $(\mathrm{Cr})$, Lead $(\mathrm{Pb})$ and Nickel $(\mathrm{Ni})$ by using AAS4129 Atomic Absorption Spectrophotometer. According to USEPA regulation for metals using TCLP leaching test, the max concentration of heavy metals for $\mathrm{Cd}, \mathrm{Zn}, \mathrm{Cr}, \mathrm{Pb}$, and $\mathrm{Ni}$ should not exceed 1.0, 5.0, $5.0,5.0$ and $3.0 \mathrm{mg} / \mathrm{l}$ respectively.

The study of morphological properties of raw dredged soil and stabilized dredged soil was done by Zeiss EVO 50 (make Germany) Scanning Electron Microscope. For testing, the soil samples were coated with thin layer of gold using a sputter coater to make them good conductor and the results of microstructure bonding of soil grains were focused at $\times 500$ magnification and at $\times 5000$ magnification.

\section{Results and discussion}

In this section results of different tests has been presented and discussed. 


\section{Compaction test}

The variations of MDD and OMC for dredged soil at different cement and cement-bottom ash mix are shown in Figs. 5 and 6.

The results of cement mix shown in Fig. 5 revealed that the value of MDD decreased from 1.64 to $1.61 \mathrm{~g} / \mathrm{cm}^{3}$ with increase of cement content to the dredged soil. But the value of OMC however increased proportionally with the increase of cement content from 16.7 to $21.23 \%$ as shown in Fig. 6. Similar trends of results had been observed by other researchers $[6,19]$.

On addition of cement-bottom ash mix to the dredged soil up to $12 \%$, the value of MDD decreased from 1.6 to $1.58 \mathrm{~g} / \mathrm{cm}^{3}$ and on further increase in cement-bottom ash content up to $20 \%$, it started increasing again. OMC trends on addition of cement-bottom ash mix are same as that of cement only.

\section{California bearing ratio test}

The CBR tests for different samples have been conducted and individual load-penetration curve are presented in Fig. 7. From the curves the CBR values are calculated

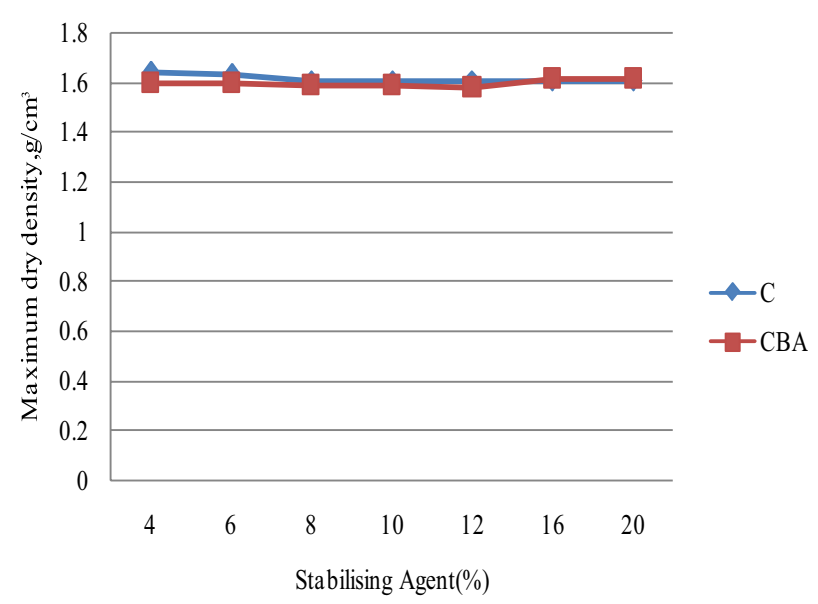

Fig. 5 Variation of MDD at different cement and cement-bottom ash mix

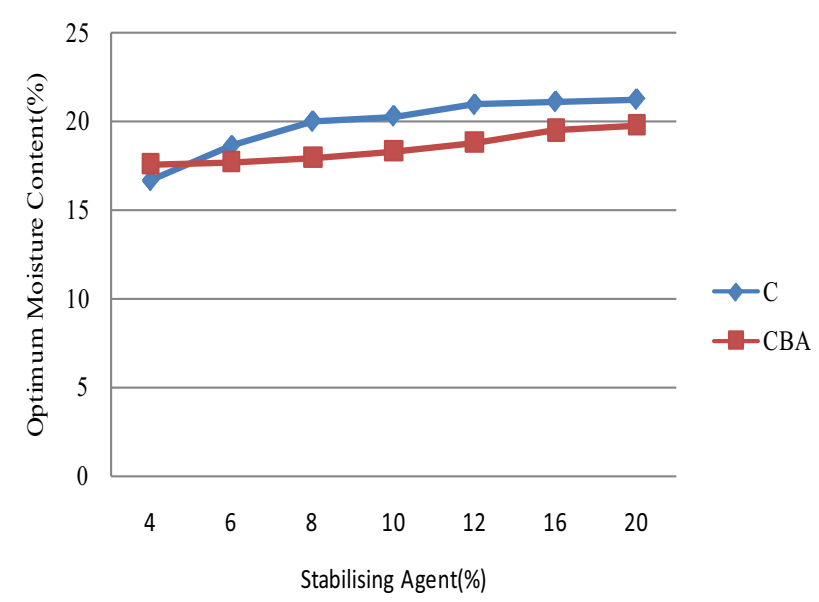

Fig. 6 Variation of OMC at different cement and cement-bottom ash mix 


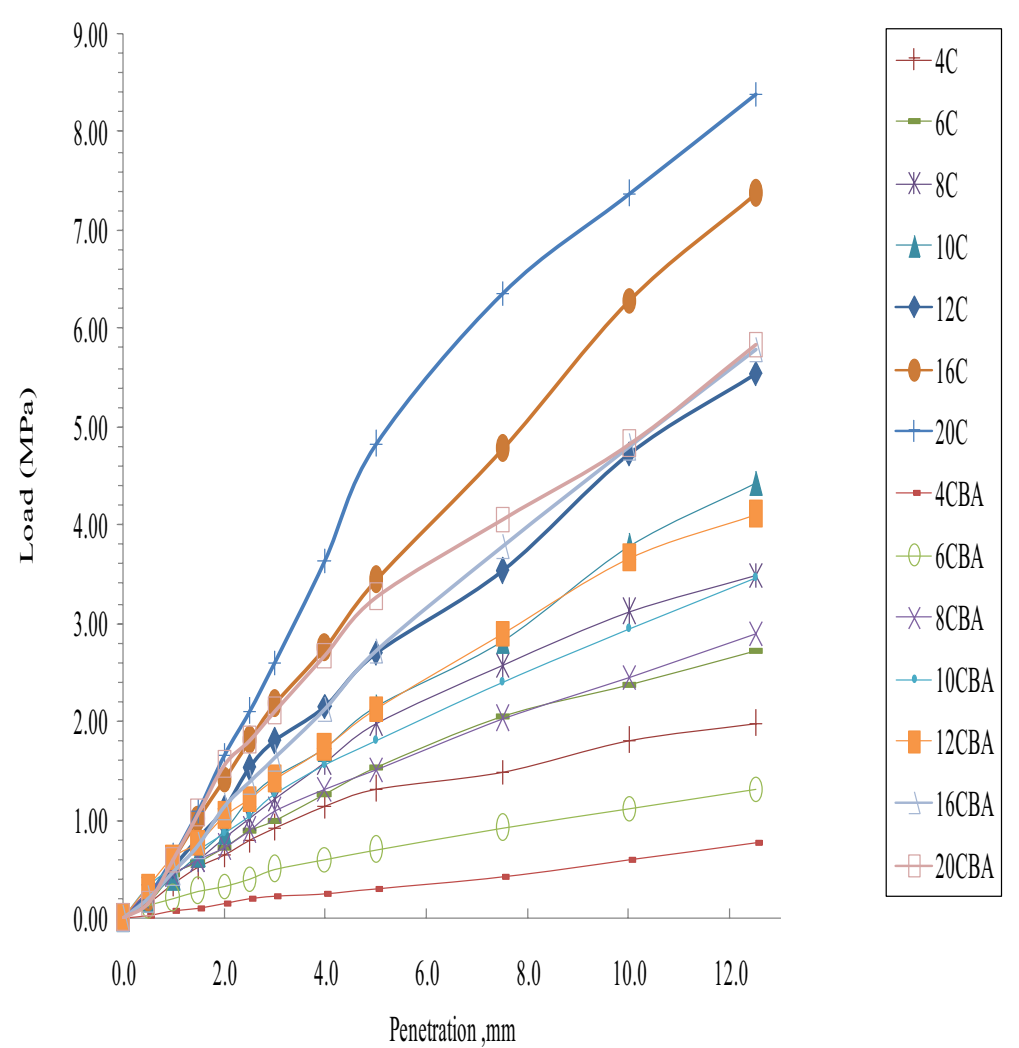

Fig. 7 Load-penetration test results at different cement and cement-bottom ash contents

in Table 6 which revealed that $5 \mathrm{~mm}$ penetration give higher values in comparison to $2.5 \mathrm{~mm}$ penetration for all specimens.

From Table 6 it has been found that CBR value increased tremendously on increase of quantity of cement as well as cement-bottom ash mix. But in comparison of cement and cement-bottom ash mix, the CBR value of the samples mixed with cement-bottom ash is higher than that of same percentage of cement only. For example, CBR value of sample $4 \mathrm{C}$ (containing $4 \%$ cement) at $2.5 \mathrm{~mm}$ penetration is 11.52 whereas for sample $8 \mathrm{CBA}$ (containing $4 \%$ cement and $4 \%$ bottom ash) it is 13.0 . This indicates that mixing

Table 6 CBR values at different cement and cement-bottom ash mix contents

\begin{tabular}{llllll}
\hline Specimen & $\begin{array}{l}\text { CBR values } \\
\text { for } \mathbf{2 . 5} \mathbf{~ m m ~ p e n - ~} \\
\text { etration (\%) }\end{array}$ & $\begin{array}{l}\text { CBR values } \\
\text { for } \mathbf{5 . 0} \mathbf{~ m m} \text { pen- } \\
\text { etration (\%) }\end{array}$ & Specimen & $\begin{array}{l}\text { CBR values } \\
\text { for 2.5 mm pen- } \\
\text { etration (\%) }\end{array}$ & $\begin{array}{l}\text { CBR values } \\
\text { for 5.0 } \mathbf{~ m m} \\
\text { penetration (\%) }\end{array}$ \\
\hline $4 C$ & 11.52 & 12.76 & $4 C B A$ & 2.87 & 3.01 \\
$6 C$ & 12.92 & 14.90 & $6 C B A$ & 5.91 & 6.71 \\
$8 C$ & 15.01 & 19.21 & $8 C B A$ & 13.00 & 14.77 \\
$10 C$ & 17.88 & 21.00 & $10 C B A$ & 15.28 & 17.63 \\
$12 C$ & 22.35 & 26.26 & $12 C B A$ & 17.79 & 20.77 \\
$16 C$ & 26.36 & 33.36 & $16 C B A$ & 20.39 & 26.48 \\
$20 C$ & 30.56 & 46.87 & $20 C B A$ & 26.29 & 31.73
\end{tabular}


of bottom ash along with cement to dredged soil enhanced the CBR values and is effective in partially replacing the cement. From the results it has also been found that all the specimens except 4CBA and 6CBA fulfilled the CBR requirements of Indian standard as well as International standards for subgrade of highway pavements.

\section{Wetting and drying test}

In wetting and drying tests, specimens $4 \mathrm{C}, 4 \mathrm{CBA}, 6 \mathrm{CBA}$ and $8 \mathrm{CBA}$ could not complete 12 cycles and failed as shown in Fig. 8 .

It is observed that the samples which passed the 12 cycles, the percentage of soilcement losses decreased with the increase in cement content as well as CBA mix content as shown in Fig. 9. It has also been found that the soil cement loss decrease from 14.78 to $0.72 \%$ with the increase of cement content from 6 to $20 \%$ whereas on increase of CBA from 10 to $20 \%$, the soil cement loss decreased from 15.04 to $6.56 \%$. From the results of wetting and drying test it has been observed that the specimens stabilized at and above $10 \%$ cement content alone and specimens at and above 20\% CBA content (1:1) fulfilled the acceptance criteria of soil-cement losses. Also in case of 20CBA, soil cement losses were found $27.27 \%$ less than $10 \mathrm{C}$ which shows that bottom ash is effective

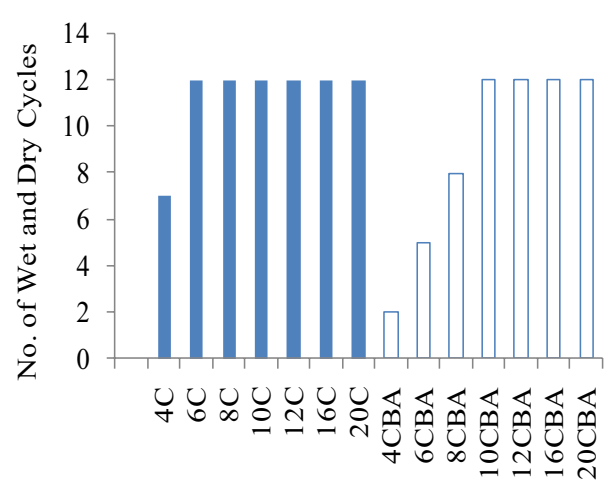

Fig. 8 Number of wetting and drying test cycles of stabilized dredged soil

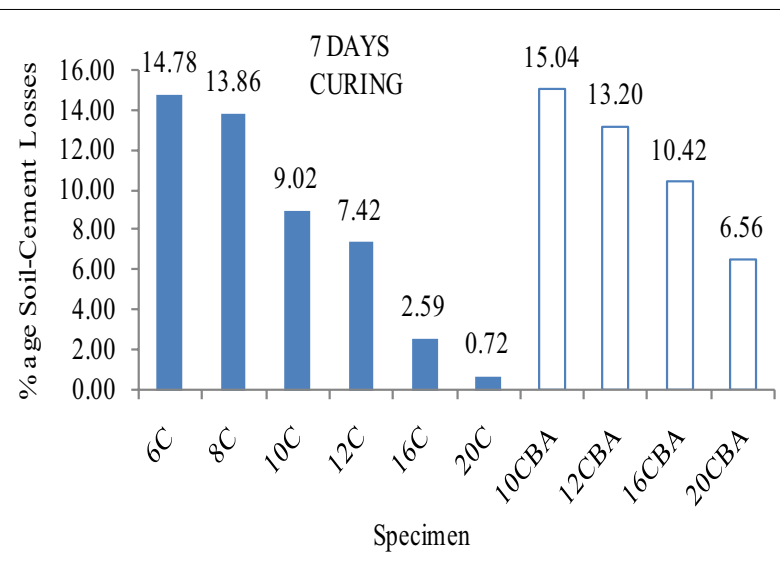

Fig. 9 Soil-cement losses for different specimens which completed 12 cycles 
in combination with cement in improving durability behaviour of the dredged soil. Thus for stabilization of dredged soil, 20CBA is more suitable than 10C only.

\section{Chemical analysis of leachate}

The concentration of heavy metal was determined at 7 and 28 days for the specimens which fulfilled the acceptance criteria of wetting and drying test i.e. 10C, 12C, 16C, 20C and 20CBA and found that the concentration of heavy metals leached decrease with increase in leaching time. After 7 days stabilization, all the samples fulfilled the maximum concentration criteria as per USEPA regulation for metals using TCLP leaching test except $10 \mathrm{C}$ and $12 \mathrm{C}$ for nickel and zinc and 20CBA for zinc only. On increasing the curing time to 28 days the leaching level of all the metals tested in the stabilized soil was below the permissible limit. The results are presented in Table 7 .

\section{Scanning electron microscope analysis}

From overall results of the case study it has been found that $10 \mathrm{C}$ and 20CBA $(10 \mathrm{C}+10 \mathrm{BA})$ samples satisfied the acceptance criteria of all the tests. The SEM analysis was performed on these specimens cured for 7 days. The SEM image showing bonding of specimen 10C and 20CBA has been shown in Figs. 10a, b and 11a, b respectively. As per SEM analysis the electrons interact with atoms of the specimens and highlight the information about the change of surface texture and its microstructures bonding. From all the figures it is evident that cement and cement-bottom ash both has significantly filled up the pores that were observed in the raw specimen analysis. The strong

Table 7 Concentration of heavy metal for different specimens after 7 and 28 days curing

\begin{tabular}{|c|c|c|c|c|c|c|c|c|c|c|}
\hline \multirow[t]{3}{*}{ Specimens } & \multicolumn{10}{|c|}{ Concentration of heavy metal in $\mathrm{mg} / \mathrm{l}$} \\
\hline & \multicolumn{2}{|c|}{ Cadmium } & \multicolumn{2}{|c|}{ Chromium } & \multicolumn{2}{|l|}{ Nickel } & \multicolumn{2}{|l|}{ Lead } & \multicolumn{2}{|l|}{ Zinc } \\
\hline & 7 days & 28 days & 7 days & 28 days & 7 days & 28 days & 7 days & 28 days & 7 days & 28 days \\
\hline $10 C$ & 0.251 & 0.018 & 0.714 & 0.062 & 3.64 & 0.166 & 0.687 & 0.062 & 16.8 & 1.520 \\
\hline $12 \mathrm{C}$ & 0.241 & 0.013 & 0.692 & 0.030 & 3.67 & 0.098 & 0.584 & 0.041 & 16.5 & 1.057 \\
\hline $16 C$ & 0.170 & 0.011 & 0.342 & 0.027 & 2.94 & 0.084 & 0.547 & 0.032 & 4.9 & 1.002 \\
\hline $20 C$ & 0.162 & 0.008 & 0.329 & 0.019 & 0.41 & 0.033 & 0.243 & 0.013 & 2.007 & 0.125 \\
\hline $20 C B A$ & 0.179 & 0.026 & 0.706 & 0.058 & 2.53 & 0.208 & 0.591 & 0.064 & 17.5 & 0.405 \\
\hline
\end{tabular}

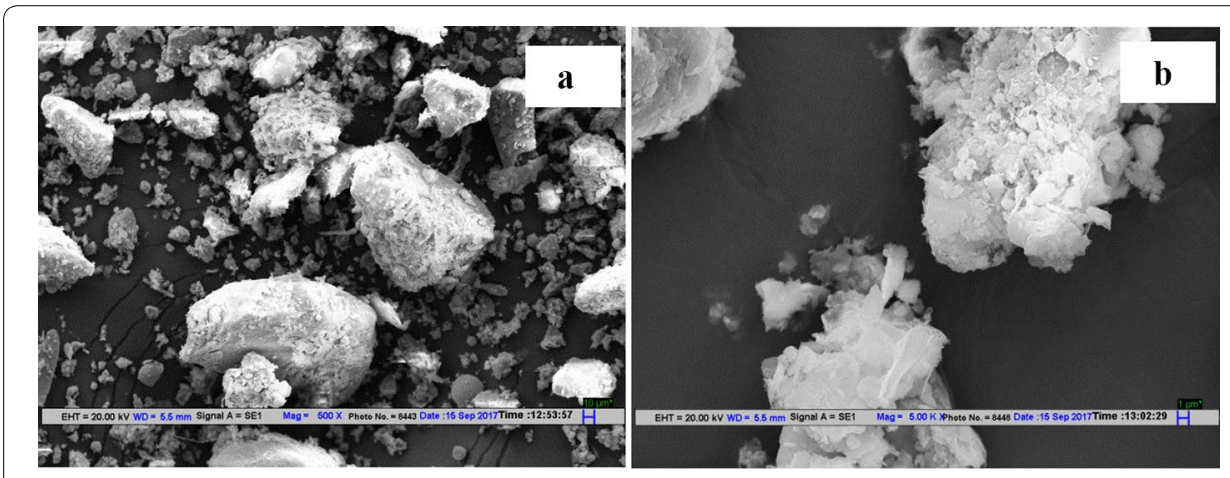

Fig. 10 SEM image of specimen $10 C$ (a) at $\times 500$ magnification and $(\mathbf{b})$ at $\times 5000$ magnification 


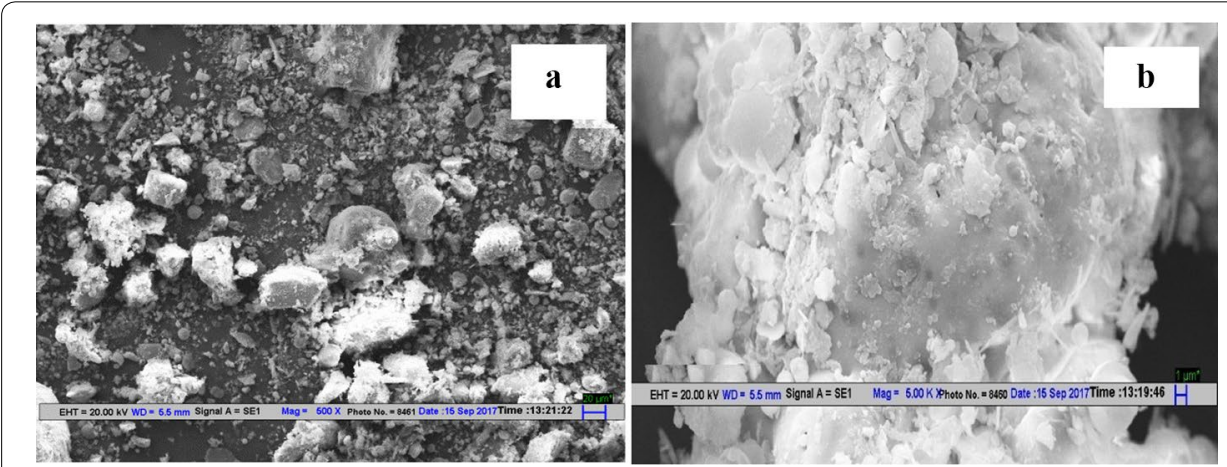

Fig. 11 SEM image of specimen 20CBA (a) at $\times 500$ magnification and (b) at $\times 5000$ magnification

interaction in between soil-cement and bottom ash may be responsible for increasing CBR values as well as improvement of durability.

\section{Conclusion}

The geotechnical and chemical properties of dredged soil of Najafgarh drain couldn't meet the criteria required for highway subgrade materials and thus stabilization using cement-bottom ash mix (1:1) has a significant role in this study. From the test results of CBR, wetting and drying and concentration of heavy metal in leachate it is found that the dredged soil stabilized with $10 \mathrm{C}$ and 20CBA (10\% cement $+10 \%$ bottom ash) both optimally fulfilled the acceptable criteria required for using it as a highway subgrade materials. But the CBR value of $20 \mathrm{CBA}$ is $33 \%$ higher in comparison to $10 \mathrm{C}$ which shows that partial replacement of bottom ash with cement was effective in improving strength of the dredged soil. The structural design i.e. thickness of layers above subgrade in highway pavements system is controlled by strength properties of subgrade. The increase in CBR value leads to design of pavements layers above subgrade with lower thicknesses (maintaining lower thickness required) without compromising pavement strength and performance. Additionally decrease in thickness will enable substantial reduction in cost of the pavement. Also, in case of 20CBA soil cement losses were $27.27 \%$ less than $10 \mathrm{C}$ which shows that bottom ash is effective in combination with cement in improving durability behaviour of the dredged soil. Thus it can be concluded that for stabilization of dredged soil, 20CBA is the most suitable mixing proportion. This study also gives a beam of light on eco-friendly use of contaminated dredged soil and bottom ash which is a great issue of concern due to its disposal.

\section{Authors' contributions}

AG carried out series of experiments and drafted the manuscript. VKA and SB have equally and continuously contributed towards supervision of the research work and revised the manuscript according to guidelines of the journal. All authors read and approved the final manuscript.

\section{Author details}

${ }^{1}$ Department of Civil Engineering, National Institute of Technology, Kurukshetra, India. ${ }^{2}$ Department of Civil Engineering, Manav Rachna International University, Faridabad, India.

\section{Acknowledgements}

The authors are thankful to Central Research Facilty, Indian Institute of Technology, Delhi for extending the laboratory facility to carry out SEM test.

\section{Competing interests}

The authors declare that they have no competing interests. 
Ethics approval and consent to participate

Not applicable.

\section{Publisher's Note}

Springer Nature remains neutral with regard to jurisdictional claims in published maps and institutional affiliations.

Received: 15 May 2017 Accepted: 2 October 2017

Published online: 24 October 2017

\section{References}

1. ASTM D559/D559 M-15 (2015) Standard test methods for wetting and drying compacted soil-cement mixtures. ASTM International, West Conshohocken. doi:10.1520/D0559_D0559M-15

2. ASTM D698 (2012) Standard test methods for laboratory compaction characteristics of soil using standard effort. ASTM International, West Conshohocken. doi:10.1520/D0698-12

3. ASTM D1883-16 (2016) Standard test method for California Bearing Ratio (CBR) of laboratory-compacted soils. ASTM International, West Conshohocken. doi:10.1520/D1883-16

4. Andrade LB, Rocha JC, Cheriaf M (2007) Evaluation of concrete incorporating bottom ash as a natural aggregates replacement. Waste Manage 27(9):1190-1199. doi:10.1016/j.wasman.2006.07.020

5. Central Pollution Control Board (2006) Water quality status of Yamuna River, New Delhi, India. http://www.cpcb.nic. in/newitems/11.pdf. Accessed 28 June 2016

6. Dutta RK, Rao VG (2005) Assessment of suitability of coralline sand-cement mixes for base/subbase courses. Bull Indian Road Congr 73

7. Environmental Protection Agency (2015) Cement manufacturing enforcement initiative. http://www.epa.gov/ enforcement/cement-manufacturingenforcement-initiative. Accessed 29 July 2016

8. Federal Ministry of Works and Housing (1997) General specifications for roads and bridges. Fed Highw Dep 2:145-284

9. Hai DH, Tho TX (2011) Particle size effect on shear properties of bottom ash added-geocomposite. J Civ Eng Archit USA 5(8):748-753

10. IRC 37 (2012) Tentative guidelines for the design of flexible pavements. Indian Roads Congress. New Delhi

11. IRC 50 (1973) Recommended design criteria for use of cement modified soil in road construction. Indian Roads Congress, New Delhi

12. IRC SP 89 (2010) Guidelines for soil and granular material stabilization using cement, Lime and Flyash. Indian Roads Congress, New Delhi

13. IS 1498 (1970) Classification and identification of soils for general engineering purposes. Bureau of Indian Standard, New Delhi

14. IS 2720, Part 7 (1980) Specifications for determination of water content, dry density relation using light compaction of Soil. Bureau of Indian Standard, New Delhi

15. IS 2720, Part 16 (1987) Method of test for soil-laboratory determination of CBR. Bureau of Indian Standard, New Delhi

16. IS 4332, Part 4 (1968) Specifications for wetting and drying, and freezing and thawing tests for compacted soil cement mixture. Bureau of Indian Standard, New Delhi

17. Irrigation and Flood Control Department, IFCD-Delhi (2016) Desilting action plan. http://delhi.gov.in/wps/wcm/ connect/doit_irrigation//rrigation+and+Flood+Control/Home. Accessed 20 June 2016

18. Jaturapitakkul CR, Cheerarot R (2003) Development of bottom ash as Pozzolanic material. J Mater Civ Eng 15(1):4853. doi:10.1061/(ASCE)0899-1561(2003)15:1(48)

19. Kim YT, Ahn J, Han WJ, Gabr MA (2010) Experimental evaluation of strength characteristics of stabilized dredged soil. J Mater Civ Eng ASCE 22(5):539-544. doi:10.1061/(ASCE)MT.1943-5533.0000052

20. Kogbara RB (2013) A review of the mechanical and leaching performance of stabilized/solidified contaminated soils. NRC Res Press 22:66-86. doi:10.1139/er-2013-0004

21. Lahtinen P, Forsman J, Kiukkonen P, Kreft-Burman K, Niutanen V (2014) Mass stabilization as a method of treatment of contaminated soils. In: Proc. of the south baltic conference on dredged materials in dike construction, Rostock

22. Maher A, Douglas WS, Jafari F (2006) Field placement and evaluation of stabilized dredged material (SDM) from the New York/New Jersey Harbor. Mar Georesour Geotechnol 24(4):251-263. doi:10.1080/10641190600788460

23. Mehraj SS, Bhat GA (2014). Cement factories, air pollution and consequences. http://www.sciencepub.net/ book/00065_book_1_65.pdf. Accessed 29 July 2016

24. Menéndez E, Álvaro AM, Hernández MT, Parra JL (2014) New methodology for assessing the environmental burden of cement mortars with partial replacement of coal bottom ash and fly ash. J Environ Manag 133:275-283. doi:10.1016/j.jenvman.2013.12.009

25. PCA (1995) Soil-cement construction handbook. Portland Cement Association (PCA) Skokie, Illinois

26. Schaefer VR,White DJ, Ceylan H, Stevens L (2008) Design guide for improved quality of roadway subgrades and subbases. In: Trans Project Reports 46. http://lib.dr.iastate.edu/intrans_reports/46. Accessed 12 Sept 2017

27. USEPA Method 1311 (1992) Toxicity characteristic leaching procedure. Test methods for evaluating solid waste, physical/chemical methods. 3rd ed. Washington

28. Wilk CM (2004) Solidification/stabilization treatment and examples of use at port facilities. In: Curtis SA (ed) Port development in the changing world. ASCE conference proceedings, Houston, Ports 2004, p 1-10. doi:10.1061/40727(2004)92 